\author{
MALGORZATA KARWATOWSKA \\ Uniwersytet Marii Curie-Skłodowskiej, Lublin, Polska \\ https://orcid.org/0000-0001-5582-3758

\section{IWONA MORAWSKA} \\ Uniwersytet Marii Curie-Skłodowskiej, Lublin, Polska \\ https://orcid.org/0000-0001-7866-2272 a
}

Copyright and License: Copyright by Instytut Języka Polskiego PAN, Kraków 2021. This article is published under the terms of the Creative Commons Attribution - NoDerivatives 4.0 International (CC BY- ND 4.0) License (https:// creativecommons.org/licenses/by-nd/4.0/legalcode.pl).

\title{
STEREOTYP KSIĘDZA „TYPOWEGO” I „PRAWDZIWEGO” W ŚWIETLE DANYCH ANKIETOWYCH
}

Słowa kluczowe: stereotyp, ksiądz „typowy”, ksiądz „prawdziwy”, student, ankieta, sondaż.

\section{STRESZCZENIE}

W artykule omówiono wyniki badań sondażowych nad stereotypem księdza „typowego" i „prawdziwego", jaki udało się zrekonstruować na podstawie wypowiedzi studentów. Badanie o charakterze diagnostycznym przeprowadzono na Wydziale Humanistycznym Uniwersytetu Marii Curie-Skłodowskiej w Lublinie. Analizę zebranego materiału ankietowego inspirowały założenia dwóch orientacji badawczych - psychosocjokulturowej i etnokognitywistycznej. Dowiodła ona m.in., że w przypadku „typowego" reprezentanta grupy respondenci wskazywali cechy księdza znanego im albo osobiście, albo z różnego rodzaju przekazów, nie tylko medialnych - dlatego wizerunek duchownego nosi wyraźne zabarwienie ambiwalentne: prezentujące zarówno pozytywne, jak i negatywne nastawienie do obiektu. Natomiast w odniesieniu do reprezentanta „prawdziwego” wymieniali wyłącznie przymioty wartościowane in plus, w wyniku czego kreowali obraz księdza takiego, jakim on według młodzieży studiującej być powinien - stąd w ich stwierdzeniach znalazły się elementy idealizacji i myślenia życzeniowego. Okazało się, że studenci postrzegają księdza przede wszystkim w dwóch funkcjach: (1) podstawowej, niejako naturalnej, czyli związanej z wykonywaniem posługi względem Kościoła i dlatego kojarzonej z pozytywnie waloryzowanymi doświadczeniami i wartościami, takimi jak: zaufanie, duchowość, pobożność, bezkompromisowość, prawda; (2) „służebnej” wobec wiernych, którzy oczekują od duchownego cech daleko wykraczających poza typowo ludzkie, a zmierzających niemal w stronę bóstwa. Zebrany materiał dowiódł dość słabej ekspozycji funkcji podstawowej. Przyczyny tego należy upatrywać w oczywistości tej funkcji-z punktu widzenia semantyki rzeczownika ksiądz. Ponadto ankietowani nie tyle charakteryzowali księdza realnego, ile kreowali jego własny obraz, własne wyobrażenia o księdzu takim, jakiego chcieliby mieć (jakim powinien być), a zatem posługa względem Kościoła schodziła na plan dalszy. Obraz księdza odtwarzany na podstawie wypowiedzi studentów lubelskich potwierdził, że w jednym stereotypie mogą spotkać się cechy zarówno pozytywne, jak i negatywne. Oceny emocjonalne, aczkolwiek wtórne wobec waloru poznawczego, są jednak bardzo istotne, ponieważ ujawniają uwarunkowania kulturowo-subiektywne. Ksiądz jest zatem dla respondentów i religijny, pobożny i chciwy, wyrachowany. 
O tym, jak istotną rolę w naszym życiu odgrywają stereotypy, nikogo już dzisiaj nie trzeba przekonywać. Są one ,„[... formą odniesienia, elementem języka koniecznym do dokonywania pewnych skrótów i uogólnień" ", tworzą teorie thumaczące świat (por. Miszewski 1998, 235). Mogą również - co oczywiste - przybierać charakter etykietek (zob. Kochan 1994), którym przypisuje się wielorakie funkcje, w tym - kognitywną, społeczną, regulacyjną, wspierającą ludzi w poznawaniu świata i orientowaniu się w nim (Quasthoff 1998). Panuje przekonanie, że - przenoszone w trakcie socjalizacji na kolejne pokolenia - stereotypowe opinie, sądy i uogólnienia usprawniają komunikację, wpływają na jej jakość, są jednym z ważniejszych czynników konstytuowania się i funkcjonowania danej społeczności, stanowią podstawę wyprowadzania określonych ocen. Stereotypy są też uznawane za swoiste filtry informacji o otaczającym świecie docierających do człowieka i za narzędzia interpretacji tego świata. Twierdzi się, że jako uogólnione wizje rzeczywistości i nośniki potocznych, konwencjonalnych znaczeń tworzą wiedzę i pamięć zbiorową. Przypisuje się im status integralnych i niezbywalnych elementów kultury, języka i komunikacji, które to elementy znajdują zastosowanie jako środki i źródła argumentacji w dyskursie publicznym:

Stereotypy odgrywają ważną rolę w dziedzinie działań społecznych [...] powiązane są z kwestiami językowymi (leksemami lub układami leksematycznymi), a ich werbalizacja wywołuje otoczkę dość mglistych asocjacji lub konotacji [...] nie wywodzą się z bezpośredniego doświadczenia jednostek, lecz z tradycji, przekazu i zapośredniczenia (Berting i Villain-Gandossi 1995, 14-15).

W myśl przyjmowanych założeń stereotypy jako specyficzne struktury kognitywne i językowo-kulturowe obrazy świata (jego poszczególnych wycinków i pojęć) okazują się silnie zabarwione podmiotowo, swoiście wewnętrznie zorganizowane, a przy tym stanowią integralną część dziedzictwa kulturowo-językowego danej społeczności czy wspólnoty komunikatywnej. Jednym z wyznaczników tak rozumianych stereotypów jest to, że obok składników wartościujących zawierają one składniki poznawcze, a w ich zasięgu mieszczą - oprócz nazw konkretnych i abstrakcyjnych pojęć, przedmiotów, ludzi, grup - zachowania człowieka, jego postawy, emocje, wyobrażenia, symbole, wartości itd. (Bartmiński i Panasiuk 1993; Kominek 2003).

Stereotypom przyznaje się bardzo duże znaczenie w tworzeniu względnie stabilnego wizerunku określonych grup i te stereotypy traktuje się jako wykładnię ich tożsamości:

Stereotyp jest niewątpliwie kategorią kulturową zajmującą w życiu społecznym miejsce szczególne. Stereotypy łączą się w pewne systemy, które mogą być rdzeniem naszej własnej tradycji [...]. Są one uporządkowanym, mniej lub bardziej spójnym obrazem świata, do którego dostrajają się nasze obyczaje, nasze gusty, nasze przyzwyczajenia i nasze nadzieje [...]. Mogą one nie tworzyć kompletnego obrazu świata, lecz obraz świata możliwego, dobrze nam znanego, dającego nam poczucie przynależności do niego - obraz [...] znajduje ona odbicie w językowym obrazie świata [...]. (Sawicka 1993, 8; zob. też: Habrajska 2008; Chodkowska 2009).

\footnotetext{
${ }^{1}$ Fragment wypowiedzi Krzysztofa Zanussiego przywołujemy za: Bartmiński (2007, 7).
} 
[S]tereotyp jest formą odniesienia, elementem języka koniecznym dla dokonywania pewnych skrótów i uogólnień (Zanussi 1995, 209).

Nic zatem dziwnego, że już dzieci operują stereotypami odnoszącymi się do płci, wieku rasy czy roli społecznej (por. np.: Biernat 1991; Macrae i in. 1999; Piaget 2005). Nie sposób nie przyznać racji badaczom, którzy utrzymują, że należałoby

[...] uznać stereotypy za część rodziny ludzkich przekonań i zrozumieć, że wywodzą się one z ogólnych procesów poznawczych, które są wspólne dla nas wszystkich (Macrae, Stangor i Hewstone 1999, 337).

Owe „obrazy w głowie ludzkiej” (Lippman 1922), niebywale jednostronne, uproszczone, cząstkowe i schematyczne (Bartmiński 2007, 54, 106), pozostają w jakiś sposób z nami na zawsze, przez co przyczyniają się do stereotypowej percepcji otaczającej nas rzeczywistości, wpływają na diagnozowanie zjawisk, ale też sprzyjają tworzeniu więzi i kontaktów społecznych. W takim rozumieniu stereotypów dopuszcza się ich zmienność:

wraz ze zmianami języka, zmianami rzeczywistości pozajęzykowej mogą zmieniać się stereotypy, przy czym jakość i kierunek tych zmian nie muszą przebiegać równolegle. I chociaż stereotypy związane z językiem i kulturą są skarbem potocznej wiedzy [...], to jednak żyją, przeobrażają się, stanowiąc element wspólnego języka i kodu kultury służącego komunikacji społecznej (Panasiuk 1998, 97).

Definicję stereotypu przyjmujemy za Jerzym Bartmińskim (2007, 70), który określa to pojęcie jako ,ustabilizowane, tzn. reprodukowane, a nie tworzone doraźnie połączenia utrwalone w pamięci zbiorowej na poziomie konkretności odpowiadającej leksemom [...]". Tak rozumiany stereotyp można rozpatrywać jako strukturę złożoną z dwóch części składowych: poznawczej i ewaluatywno-emocjonalnej. Pierwsza sprowadza się do charakterystyki określonej grupy osób bądź rzeczy, powiązanych z nazwą kategorii w pamięci schematycznej, natomiast druga dotyczy nacechowania emocjonalnego danego stereotypu, które uwidacznia się podczas jego aktywizacji. W studiach nad stereotypami rozróżnia się stereotypy kulturowe: zbiorowe, grupowe i indywidualne, będące swoistymi konstruktami pojęciowo-mentalnymi.

Jako konwencjonalne, utarte wyobrażenia podzielane przez wielu członków wspólnoty komunikatywnej, stereotypy «mieszkają w języku» [...], służą szybkiej komunikacji przez odwołanie się do wspólnych wartości, oceny, wiedzy, wspólnych doświadczeń, podobnej wrażliwości. Są więc pożyteczne. [...] jak wszystkie znaki językowe - mogą też być używane ze złą wolą, z mniej lub bardziej jawną intencją obrażania, poniżenia i dyskredytowania (Bartmiński 2011, 36).

Niebywale istotne stały się dla nas spostrzeżenia Wojciecha Chlebdy, który wskazał na dwie orientacje badawcze: psychosocjologizującą i etnokognitywistyczną:

Stereotyp w lingwistyce traktowany jest niejako dwubiegunowo. Część językoznawców skupia się głównie na powierzchniowej, ,,widzialnej”, czysto lingwistycznej stronie stereotypu, opisując pod jego etykietą reprodukowane z pamięci związki wyrazowe[,] i przeciwstawia je konstruowanym doraźnie produktom 
językowym[, natomiast drugą interesuje] warstwa głęboka stereotypu, jego strona mentalna, czyli specyficzne zespoły sądów o wycinkach rzeczywistości, jakie tkwią w świadomości mówiących $(1998,32)$.

Zwracamy uwagę na te dwie orientacje badawcze, gdyż celem naszych dociekań jest próba zrekonstruowania obrazu księdza wyłaniającego się z wypowiedzi studentek i studentów lubelskich. Analizę zebranego materiału opieramy na badaniach ankietowych ${ }^{2}$, uznanych przez nas za odzwierciedlające najbardziej aktualny wizerunek księdza w tej grupie respondentów. We wcześniejszej naszej pracy (Karwatowska i Morawska 2021), także dotyczącej księdza, poprosiłyśmy respondentów o (1) podanie wszystkich słów, zwrotów, powiedzeń, które przychodzą im na myśl, kiedy słyszą rzeczownik ksiądz (były to skojarzenia swobodne ${ }^{3}$, otrzymane w sposób ciągły) oraz o (2) skonstruowanie własnej definicji tego słowa ${ }^{4}$. Okazało się - co nie było dla nas zaskoczeniem - że w definicjach studenckich bardzo mocno uwidacznia się

${ }^{2}$ Badanie o charakterze diagnostycznym przeprowadzono na Wydziale Humanistycznym Uniwersytetu Marii Curie-Skłodowskiej w Lublinie. Uczestniczyło w nim łącznie 130 studentów. Zdaniem Tadeusza Pilcha $(1998,117-118)$ taka grupa jest kwalifikowana jako duża. Wypada także zaznaczyć, że interesująca byłaby odpowiedź na pytanie, czy respondenci pochodzący z innych miast uniwersyteckich udzieliliby podobnych odpowiedzi: czy stosunek do Kościoła katolickiego jest taki sam w Warszawie, Katowicach, Gdańsku czy we Wrocławiu. Rozstrzygnięcie tych wątpliwości znajdzie się w kolejnym naszym tekście.

${ }^{3}$ Skojarzenie to proces polegający na połączeniu wrażeń i wyobrażeń czy innych zjawisk psychicznych w taki sposób, że pojawienie się w świadomości jednych skutkuje uświadomieniem sobie innych. Tak więc skojarzone rzeczy, sprawy, zjawiska muszą wykazywać jakiś wzajemny związek. Wśród testów skojarzeń Władysław Miodunka (1989) wyróżnia: ograniczone (jedno hasło wymaga jednej reakcji słownej) i ciągłe (do jednego hasła respondent dopisuje szereg skojarzeń w określonej jednostce czasu). W sytuacji, gdy mamy na myśli pierwsze reakcje słowne, mówimy o skojarzeniach swobodnych, a jeśli od badanego oczekujemy reakcji określonego typu - mamy do czynienia ze skojarzeniami kierowanymi.

${ }^{4}$ Należy wyjaśnić, że wśród asocjacji wymienianych przez ankietowanych (o czym pisałyśmy we wcześniejszym tekście, por. Karwatowska i Morawska 2021) znalazły się określenia nacechowane niezwykle pozytywnie (np.: glosiciel Dobrej Nowiny, pasterz, posłaniec Boga, stuga Boży, uosobienie Jezusa/Boga), ale zdecydowanie częściej wskazywane były te silnie wartościujące in minus (np.: gwatciciel, pedofil/pedofilia, alkoholik, pijak, złodziej, tasy na pieniadze, nastawiony na pieniądze / na zysk). Obok braku szacunku dla drugiego człowieka, studenci zarzucali księdzu niewiedzę, czerpanie korzyści z własnej przebiegłości, oszukiwanie innych (brak szacunku dla innych pogladów; czlowiek sprytny, wie, jak się ustawić w życiu; mówi o wszystkim, a nie zna się na niczym; szerzenie glupoty, zabobonu, potwierdzenie teorii głoszacej, iż większość ludzi (wszyscy) tatwo poddaja się autorytetowi i chca mieć nieistniejace oparcie w wyimaginowanej osobie; ktoś, kto lud tumani i z niego kpi). Niekiedy oceny ujemne sygnalizowano nie wprost, np.: mafia, polityka, dąży do władzy, powinien być elastyczny, powinien czuć powołanie, nie powinien gonić za pieniadzem. Czasownik modalny powinien znalazł się również w wielu objaśnieniach słowa konstruowanych przez młodych ludzi, np.: ksiądz to czlowiek, który powinien czuć powołanie, by stużyć Bogu i innym ludziom; powinien posiadać wysoki poziom wrażliwości na otaczający go świat; powinien kochać ludzi, w pierwszej kolejności skupiać się na bliźnim; powinien być gotowy/zdolny do (calkowitego poświęcenia) poświęceń; powinien chcieć naprawdę glosić słowo Bożę; powinien być pewny tej decyzji; powinien uczyć innych mitosierdzia, miłości dla drugiego człowieka, mądrości życiowej. To verbum bardziej ujawnia oczekiwania piszącego wobec księdza niż rzeczywiste postępowanie konkretnych osób w tej roli. Respondenci stosunkowo często wskazywali zatem na to, jaki ksiądz powinien być lub też czego nie powinien robić. Okazało się, że o ile definicje konstruowane przez młodzież akademicką niosły przede wszystkim wartościowanie pozytywne 
stereotypowe postrzeganie księdza. Zgadzamy się z Bartmińskim (zob. 1998, 74-75; 2006, 15), że stereotypy językowe funkcjonują z ujawnionym bądź nieujawnionym modyfikatorem ,prawdziwy”, którego sens modalny oscyluje w języku potocznym między 'jest' a 'powinien być'. Tym razem zamierzamy zrekonstruować ów stereotyp na podstawie dwóch poleceń, które dotyczyły cech księdza „typowego” oraz „prawdziwego” (więcej o różnicy między tymi modyfikatorami - zob. Bartmiński 1994; Fleischer 2002; Wasiuta 2009). Dyspozycja, w której zwróciłyśmy się z prośbą do studentów o podanie cech ,typowego” księdza, przyniosła w odpowiedzi prawie 200 określeń, natomiast polecenie o wskazanie cech „prawdziwego” księdza przełożyło się na niemal 140 określeń.

Zasadne wydaje się w tym miejscu pytanie, które w jednym ze swych artykułów zadał już Bartmiński $(2007,74)$ : ,ile wyborów winno paść na cechę, by móc ją uznać za składnik treści stereotypu językowego?’. Choć zgadzamy się, że poziom częstości cech jest istotny, to w trakcie analiz będziemy się odwoływały zarówno do cech ze środka, jak i z końca listy, czyli nawet do jednostkowych wskaźników wyborów - ponieważ wychodzimy z założenia, że niska pozycja cechy na liście nie wyklucza ważności czy znaczenia. Nawet ,cechy podawane jednorazowo powiązane są ze sobą - i z cechami częstymi - siecią wzajemnych implikacji, nie można ich więc z góry uznawać za nieważne z punktu widzenia treści stereotypu”, tym bardziej że „na gruncie stereotypu językowego mamy [...] do czynienia z myśleniem nie kategoriami ilości, lecz «reprezentatywności»" (Bartmiński 2007, 90, 83).

Spróbujmy zatem poddać szczegółowszym obserwacjom odpowiedzi respondentów wyekscerpowane z kwestionariuszy ankiet. Aby uprzedzić dalsze analizy, chcemy raz jeszcze podkreślić, że lista cech, ułożona w kolejności od najczęściej do najrzadziej wymienianych, okazuje się długa. Nie są to wyłącznie cechy esencjalne (które przysługują wszystkim obiektom klasy) - to przede wszystkim cechy typowe albo inaczej zwyczajne, normalne. Zestawy tych cech tworzą językowo-kulturowy obraz księdza.

Do najczęściej wymienianych cechy „typowego” księdza należały:

- nastawiony na zysk, na dobra materialne (goniacy za pieniadzem / łasy na pieniadze / łakomy na pieniądze / nastawiony na pieniadze / myśli tylko o pieniądzach / wszędzie szuka zysku) - 455;

- irytujący, ma poczucie wyższości, nietolerancyjny - 23;

- $\quad c h c i w y-18$

- godny zaufania, obłudny - 14;

- $\quad$ wiara (głęboka, prawdziwa), wierzacy - 12;

- dobry, mądry, nieczuły, pomocny, prostak - 8;

- bogaty, ciekawski, cierpliwy, gruby, obłudny, otyły, zawistny, złodziej, wyksztatcony - 6;

albo neutralne (wynotowałyśmy zaledwie pięć objaśnień nacechowanych in minus), o tyle skojarzenia zawierały zdecydowanie większy ladunek negatywny. Zob. także: Szauer (2020, 129-145).

${ }^{5}$ Cyfra oznacza liczbę osób wymieniających daną cechę. 
- bezczelny, egocentryk, egoista, fałszywy, pijak, poważny, surowy, zachłanny, zakłamany, zawistny - 5;

- empatyczny, gwałciciel, inteligentny, konserwatywny, poważny - 4;

- chamski, dobroduszny, mity, nie przejmuje się opinia publiczna (ma w nosie opinie publiczna), oczytany, opanowany, otwarty (na ludzi / na innych), pewny siebie, pobożny, pyszny, seksista, skapy, spokojny, sprawiedliwy, szczery, szowinista, tradycjonalista, uczciwy, religijny, wyważony - 3 .

Po uwzględnieniu wyborów, nie tylko najczęstszych, lecz także jednostkowych, należy stwierdzić, że cechy, określenia, przymioty kojarzone z księdzem dały się przyporządkować do co najmniej kilku sfer:

- $\quad$ ekonomicznej, majątkowej: nastawiony na zysk, na dobra materialne (goniacy za pieniądzem / łasy na pieniądze / łakomy na pieniądze / nastawiony na pieniądze / myśli tylko o pieniądzach / wszędzie szuka zysku) - 45, bogaty - 6, chciwy - 18, zachłanny - 5, skapy - 3, pazerny - 1 wyrachowany - 1;

- duchowej, religijnej: wiara (głęboka, prawdziwa), wierzacy - 12, pobożny - 3, religijny - 3, oddany Bogu - 1, uduchowiony - 1, skupiony na Kościele i wierze 1, dbajacy o właściwe przekazanie słowa Bożego - 1;

- $\quad$ społecznej (stosunek do drugiego człowieka / relacje międzyludzkie): ma poczucie wyższości - 23, nietolerancyjny - 23, dobry - 8, pomocny - 8, surowy - 5, empatyczny - 4, chamski - 3, dobroduszny - 3, opanowany - 3, seksista - 3, sprawiedliwy - 3, szowinista - 3, człowiek o dobrym sercu - 1, miłosierny - 1, niezainteresowany potrzebami innych ludzi - 1, pouczajacy innych - 1, pozbawiony wrażliwości dla drugiego człowieka - 1, rozmowny - 1, wyrozumiały - 1;

- intelektualnej i charakterologicznej: madry - 8, wykształcony-6, inteligentny - 4, oczytany - 3, cierpliwy - 6, dowcipny - 1, dumny - 1, fanatyczny - 1, konserwatywny - 1, mity - 1, odpowiedzialny - 1, sprytny - 1, stanowczy - 1, zabawny - 1;

- $\quad$ obyczajowej: złodziej-6, pijak-5, gwałciciel-4.

W pytaniu o cechy ,prawdziwego” księdza najczęstszymi określeniami były:

- dobry - 40;

- otwarty (na ludzi / na świat / na drugiego człowieka), pomocny, skromny - 36;

- godny zaufania, można mu zaufać, wzbudza zaufanie - 32;

- mity, szczery, tolerancyjny, wyrozumiaty - 28;

- oddany Bogu (całkowicie, w petni), uczciwy - 20;

- bezinteresowny, cierpliwy, madry, spokojny - 17;

- empatyczny, powolanie (prawdziwe, szczere) - 15;

- $\quad$ nieosadzajacy (pochopnie, zbyt szybko), pobożny, pokorny - 10;

- $\quad$ apolityczny (nie miesza się w politykę), uczynny, serdeczny, sprawiedliwy - 7;

- odpowiedzialny, przestrzega zasad, które sam głosi / trzyma się zasad, uprzejmy, (zawsze) stuży (dobra) rada i pomocna dtonia - 5;

- $\quad$ altruista, kocha ludzi, kulturalny, lubi drugiego człowieka, nie dba o dobra materialne, oddany (drugiemu człowiekowi, ludziom), wesoły, wierny słowu Bożemu - 4; 
- dobroduszny, inteligentny, uśmiechnięty, sympatyczny, wierny Bogu, wrażliwy, $\dot{z y c z l i w y}-3$.

Dyspozycja dotycząca wskazania cech ,„prawdziwego” księdza dowiodła, że młodzi ludzie chcieliby postrzegać go jako kogoś wyjątkowego, idealnego, o nienagannym, nieskazitelnym wręcz postępowaniu, kogoś na wzór anioła, wolnego od ludzkich przypadłości, wad, nałogów, pokus czy jakichkolwiek słabości - czego potwierdzeniem były następujące odpowiedzi ankietowanych: duchowy ojciec, pozbawiony wad, przepetniony wzniostymi wartościami, uduchowiony, wzór do naśladowania ${ }^{6}$.

Cechy przypisywane księdzu wymieniane przez młodych ludzi często sytuują się między dwoma biegunami, np.: altruista-egoistalegocentryk, prawdomówny-zakłamany, cierpliwy - niecierpliwy/nerwowy, dobry - zły, moralny - amoralny, skapy - rozrzutny, konserwatywny - postępowy, tolerancyjny - nietolerancyjny/fanatyczny, kulturalny chamski, mity/sympatyczny - opryskliwy, empatyczny - samolubny, hojny - chciwy, wykształcony - niedoedukowany, szczery - fatszywy/obłudny, nie jest seksista-seksista. Te przeciwstawne określenia dotyczą oceny i zawierają niekiedy silny ładunek emocjonalny, który może - po pierwsze - być skutkiem negatywnego prezentowania przedstawicieli tego zawodu w mediach (prasie, radiu, telewizji, internecie, kinie) ${ }^{7}$, po drugie - wynikać z indywidualnych doświadczeń, z jakimi zetknęła się osoba udzielająca odpowiedzi, a po trzecie wreszcie (co ma związek z dwoma wcześniejszymi punktami) - może być efektem rozczarowania respondenta, który chciał albo chce widzieć w przedstawicielu duchowieństwa wzór, autorytet (Treder 2007, 2008), a ów odbiega od jego oczekiwań. Antonimy właśnie jednoznacznie dowodzą ambiwalencji w postrzeganiu księdza. To zjawisko wpisuje się w - szeroko omawianą w literaturze przedmiotu - koncepcję ,życia z ambiwalencją”, którą uznaje się za immamentny składnik „naszej” współczesności

${ }^{6}$ Tego rodzaju określenia wykazują wiele wspólnego z obrazami księdza propagowanymi w podręcznikach szkolnych do religii dla licealistów, których zawartość była przedmiotem badań w artykule Lucyny Wardy-Radys i Anety Lewińskiej. Autorki konkludują w nim: „Zebrany podczas analizy tekstów materiał pokazuje, że [...] licealista spotyka się z księdzem dalekim (częściej z dostojnikiem kościelnym niż parafialnym duszpasterzem), należącym bardziej do sfery sacrum, pośredniczącym w kontaktach człowieka z Bogiem, raczej nauczającym niż rozmawiającym" (Warda-Radys i Lewińska 2011, 494).

7 Wystarczy wskazać kilka tytułów artykułów zamieszczonych w Polityce, np.: J. Podgórska, „Wstyd i zgorszenie” (2018, nr 36); „Wspólnota milczenia”, rozmowa z Pawłem Dobrowolskim (2018, nr 46); R. Socha, „Sąd nad pamięcią” (2019, nr 1); J. Podgórska, „Księża i książęta” (2019, nr 25); J. Wróblewski, „My nie zawiedliśmy” (2020, nr 20); J. Podgórska, „Lawendowa familia” (2020, nr 23). Tytuły, przywołane niezwykle wybiórczo, dowodzą, że temat księży i Kościoła jest wciąż aktualny na łamach prasy. Jednak nie tylko prasa kreuje obraz księdza. W 2019 roku mogliśmy obejrzeć polski film dokumentalny w reżyserii Tomasza Sekielskiego zatytułowany Tylko nie mów nikomu. Bracia Sekielscy - Tomasz i Marek - 16 maja 2020 roku udostępnili na YouTube drugą część dokumentu o pedofilii w Kościele, tym razem zatytułowaną Zabawa w chowanego. Wykorzystywanie seksualne małoletnich przez księży katolickich w Polsce i ukrywanie tych praktyk przez kościelnych hierarchów wzbudza olbrzymie emocje nie tylko wśród internautów. „Sprawcy w koloratkach” (określenie Sekielskich), mimo medialnej burzy, unikają na ogół odpowiedzialności. Rolę księdza w społeczeństwie polskim prezentują także dwa filmy obyczajowe: Kler w reżyserii Wojciecha Smarzowskiego i Boże Ciało w reżyserii Jana Komasy. Wypada także wymienić niektóre stacje telewizyjne, np. Polsat, TVN 24 i radiowe, np. Tok FM, które zajmują się m.in. problemem pedofilii w Kościele. 
i jej kluczowy wyznacznik (zob. Gnitecki 1998; Nowak-Łojewska 2005). Podkreśla się przy tym - co ważne - że

[...] ambiwalencji nie należy pojmować wyłącznie jako chaos, deficyt porządku, ale nieusuwalny warunek towarzyszący ludzkiej egzystencji, [...] wręcz nieredukowalny aksjomat opisu bytu społecznego (Witkowski 1994, 47-48).

Zdaniem wielu badaczy ambiwalencja może być szansą wyzwolenia człowieka z wieloznacznej dwuznaczności i sprzyjać emancypacji dzięki zdolności łączenia i przechodzenia między różnymi formami racjonalności. W konsekwencji okaże się, że:

[...] tradycyjny dylemat dotyczący dokonywania wyborów pomiędzy kontrastującymi wizjami może zostać przekroczony. Wówczas nie wystarczą same kanony wiedzy czy zastępowanie ich inwariantami, lecz potrzebne stanie się budowanie mądrości rozumienia świata na podstawie pewnego trzonu, przy zachowaniu możliwości rozpatrywania go w wielości i różnorodności (Nowak-Łojewska 2002, 22).

Wśród zróżnicowanych typów ambiwalencji naszą szczególną uwagę zwróciło ujęcie, w myśl którego zjawisko to jest rozumiane jako oscylacja, czyli chwianie się w wyborze między dwiema możliwościami lub też skłanianie się raz w jedną, raz w drugą stronę. Może ono też przybrać postać tzw. ambiwalencji zrównoważonej, która nie redukuje antynomii i sprzeczności, ale równoważy je na wielu poziomach i w wielu zakresach ich występowania. Znalazło to potwierdzenie w naszych badaniach, kiedy nadmiernie surowe oceny księdza łagodzone były partykułami: trochę, troszkę i przysłówkiem nieco, komunikującymi, że stopień cechy albo zakres stanu rzeczy, o którym mowa, nie jest duży - stąd wypowiedzi: troszkę skapy, trochę wredny, nieco samolubny, nieco zadufany w sobie. Sygnalizowane zjawisko wykazuje wiele wspólnego z wynikami badań religijności młodzieży koszalińsko-kołobrzeskiej, która

bardziej ceni kompetencje naturalne niż kwestie związane z duchowością. W wypowiedziach badanych
młodych bardzo wysoko cenione są cechy osobowe duszpasterza, takie jak: uczciwość, przystępność,
otwarcie na dialog, umiejętność słuchania, kultura osobista, szacunek do człowieka, kompetencja
intelektualna oraz... poczucie humoru. Z cech religijnych istotne jest dla respondentów wykazywanie
się przez kapłana powołaniem i nietraktowanie bycia księdzem jako pracy zarobkowej, głęboka wiara,
modlitwa, staranność liturgiczna, ale też bardzo praktyczne pastoralnie kwestie - umiejętność głoszenia
kazań i spowiadania, gdzie znów istotne znaczenie mają: empatia i umiejętność słuchania (Szauer 2019b).

Przeprowadzone przez nas badanie dowiodło, że w przypadku „typowego” reprezentanta grupy respondenci wskazywali cechy księdza znanego im albo osobiście, albo z różnego rodzaju przekazów (nie tylko medialnych). Dlatego wizerunek duchownego nosi wyraźne zabarwienie ambiwalentne - prezentujące zarówno pozytywne, jak i negatywne nastawienie do obiektu. Natomiast w odniesieniu do reprezentanta „prawdziwego" wymieniali wyłącznie przymioty wartościowane in plus, w wyniku czego kreowali obraz księdza takiego, jakim on według badanych być powinien - stąd wprost elementy idealizacji i myślenia życzeniowego. Innymi słowy: wartości intelektualne, czyli gruntowna wiedza, rzeczowość wypowiedzi, umiejętność intersującego wygłaszania kazań, 
połączone z wartościami moralnymi, a zatem cierpliwością, życzliwym stosunkiem do drugiego człowieka, gotowością do wsparcia i zrozumienia oraz atrakcyjność zewnętrzna duchownego, a więc miły głos, poczucie humoru i ogólna kultura - te cechy tworzą obraz oczekiwany przez badanych. Taka kreacja nie dziwi, albowiem:

Dla stereotypu - jak utrzymuje Bartmiński (2007, 109) - charakterystyczna jest właśnie obecność elementu przekonaniowego, poniekąd ,mitologicznego”, tj. nakładanie na obraz tego, co jest, wyobrażenia tego, co zdaniem mówiących - być powinno. Inaczej mówiąc - stereotyp opiera się na pewnych z góry założonych tezach, niepoddawanych krytyce, przyjmowanych - jak to się mówi - ,z mlekiem matki”, tj. z kulturą lokalnego środowiska (podobnie jak to ma miejsce w przypadku podstawowych wartości czy przekonań religijnych).

Co ciekawe - i co wynika z naszego wcześniejszego tekstu (Karwatowska i Morawska 2021), jak i ustaleń innych badaczy (por. np. Bartmiński 2007, 102) - ksiądz najczęściej jest postrzegany poprzez strój (czarne szaty, kiecka, koloratka, ornat, specyficzny ubiór, stuła, sutanna) oraz miejsce (kościót, kancelaria, kaplica, konfesjonat, plebania, zakrystia), a także sytuację materialną (bogactwo, limuzyna, pieniądz/pieniądze, przepych) i obyczaje, zachowania wartościowane zarówno pozytywnie (opiekun, pomocnik, powiernik, przewodnik duchowy, przyjaciel, ten, który wskazuje drogę), jak negatywnie (gbur, gwatciciel, krętacz, małostkowy, nadęty, nietolerancyjny, obludny, oszust, zadufany w sobie, złodziej). W analizowanym tu materiale cechy orzekane o księdzu, obok tych odnoszących się do powołania (powołanie prawdziwe, szczere / brak powołania, gluchy na głos Boga), zawierają odniesienia do jego charakteru i usposobienia (mity, uczynny, serdeczny, spokojny, sprawiedliwy, tolerancyjny, uczynny, wesoly, wyrozumiały, wrażliwy/chamski, chciwy, chytry, egocentryk, fatszywy, interesowny, konserwatywny, nadęty, obludny, opryskliwy, wyrachowany) oraz intelektu (elokwentny, inteligentny, madry, oczytany, wyksztatcony / brak wiedzy, niedoedukowany, waskie horyzonty umysłowe), ale nade wszystko odnoszą się do stosunku duchownego do drugiego człowieka (kocha ludzi, lubi drugiego czlowieka, oddany (drugiemu czlowiekowi, ludziom), osoba, na która zawsze można liczyć w trudnych chwilach, otwarty [na ludzi / na drugiego człowieka], pomaga parafianom, pomaga wiernym osiagnać zbawienie, pomocny, udziela budującej krytyki, wspiera swoich wiernych / brak wrażliwości na innych ludzi, latwo osadzający innych, nakazuje ludziom, jak maja żyć, niechętny do rozmowy z ludźmi, gdy oni zadaja pytania, mało zainteresowany potrzebami innych ludzi, przejawia nienawiść do drugiego człowieka, uważa się za lepszego od innych, skłonny do dyskryminacji).

Na podstawie zebranego materiału można wysnuć wniosek, że gdy ankietowani wymieniają cechy księdza, na plan pierwszy wysuwają własną osobę, a dopiero poprzez pryzmat osobistych odczuć i potrzeb formułują ocenę duchownego. Stąd wzięły się wypowiedzi typu: czlowiek, z którym da się pogadać, pożartować, potrafi utrzymać dobry kontakt z młodzieża, rozumie młodych ludzi itd. ${ }^{8}$ Ta subiektywna perspektywa

\footnotetext{
${ }^{8}$ Taka strategia obrazowania księdza została rozpoznana także w podręcznikach do religii dla gimnazjalistów: „Gimnazjalista odnajdzie w swoich podręcznikach księdza, którego spotyka w szkole i w parafii, budującego swój autorytet podczas dialogu z uczniem” (Warda-Radys i Lewińska 2011, 494).
} 
sprawia, że respondenci z dezaprobatą, a może - i z odrobiną ironii, odnoszą się do księży, którzy z wyższością traktują innych: pouczają ich, przechwalają się swoją wiedzą, np. przemadrzaty, wszechwiedzący, wszystkowiedzacy.

Niektórych cech księdza nie sposób ocenić jednoznacznie in plus bądź in minus. Chodzi o następujące określenia: rygorystyczny, surowy, urzędnik. Ktoś surowy czy rygorystyczny jest $-\mathrm{z}$ jednej strony - wymagający, ale z drugiej - może okazać się także bezwzględny w egzekwowaniu obowiązków lub posłuszeństwa. Z kolei urzędnik to osoba, która sprawnie wykonuje swoje zadania, ale może wykazywać nieżyczliwość wobec osób, które obsługuje, a nawet - potwierdzić swoje niekompetencje (por. epitet urzędas).

Wypada także odnotować, że sporadycznie w kwestionariuszach ankiet pojawiały się cechy odnoszące się do powierzchowności i wieku księdza, które niosły ze sobą wartościowanie negatywne: gruby, otyły, spaślak / w podeszłym wieku, leciwy. Pozostają one w sprzeczności z wymienionymi wcześniej, zgodnie z którymi ksiądz wchodzi we właściwe interakcje z młodzieżą, rozumie jej problemy, ma z nią niejednokrotnie partnerskie czy niemal koleżeńskie relacje.

Obydwa obrazy księdza: „,prawdziwego" i ,typowego”, odtworzone na podstawie danych wyekscerpowanych z ankiet, zależą - naszym zdaniem - również od nadawcy, jako konstruowane $\mathrm{z}$ określonego punktu widzenia. Pewne aspekty tej osobistej perspektywy wysuwają się na plan pierwszy, inne profile pojęcia zostają zepchnięte na plan dalszy lub wyeliminowane. Analogiczne badanie przeprowadzone na innej grupie respondentów mogłoby ujawnić wizerunek nieco odmienny od otrzymanego, ale cechy esencjalne (tj. przypisywane wszystkim księżom) prawdopodobnie pozostałyby bardzo zbliżone (zob. np. Szauer 2019a).

Inne ważne - jak się wydaje - spostrzeżenie wyprowadzone $\mathrm{z}$ analiz potwierdziło raz jeszcze, że cechy typowe dla stereotypów to przede wszystkim: powszechność, trwałość, apoznawalność, nasycenie afektywne i uogólnienia, bardzo często oparte na braku zgodności między sądem a rzeczywistością (Łukaszewski i Weigl 2001, 45). W przypadku księdza jego stereotypowe wyobrażenie jest już w języku i kulturze ugruntowane. Wykonywanie tej profesji sięga tradycją dawnego stanu duchownego. Nie dziwi zatem, że obrosło w różnego rodzaju wyobrażenia, charakterystyczne cechy, zalety i przywary. $\mathrm{Na}$ potrzeby tego artykułu warto jedynie wspomnieć, że duchowieństwu - z jednej strony były od dawien dawna przynależne atrybuty świadczące o doniosłej roli w rozwoju kultury (m.in.: mądrość, szlachetność, dostojeństwo, prawość, poszanowanie, autorytet itd.), zwłaszcza jeśli chodzi o piśmiennictwo, naukę, szkolnictwo, kształtowanie stosunków społeczno-politycznych. Jednak z drugiej strony - duchowni byli pod obstrzałem mniej

\footnotetext{
${ }^{9}$ Świadczą o tym - przykładowo - literackie kreacje księży (postaci autentycznych i fikcyjnych): bohaterów, męczenników, ludzi nieugiętych, bezkompromisowych, zatroskanych o wiernych, o los ojczyzny, o wartości, „głos sumienia”, duchowy wymiar ludzkiej egzystencji itd.: Pieśń o św. Stanisławie, ksiądz Marek - tytułowy bohater dramatu Juliusza Słowackiego, o. Augustyn Kordecki z Potopu Henryka Sienkiewicza, księża w utworach Adama Mickiewicza, zwłaszcza ksiądz Robak z Pana Tadeusza, czy ksiądz Piotr z Dziadów część III, święty Franciszek z powieści Gilberta Keitha Chestertona Święty Franciszek
} 
lub bardziej ostrej krytyki wymierzonej przeciwko temu, co w świetle opinii publicznej przeczyło nauce Kościoła przez nich głoszonej (np.: materializm, interesowność, upolitycznienie, pycha, zaniedbywanie obowiązków kościelnych, rażące łamanie zasad moralnych, obłuda, wywyższanie się, bezkrytyczność, uprzywilejowanie) ${ }^{10}$. Sądzimy, że studenci postrzegają księdza przede wszystkim w dwóch funkcjach:

- $\quad$ podstawowej, niejako naturalnej, czyli związanej z wykonywaniem posługi względem Kościoła i dlatego kojarzonej z pozytywnie waloryzowanymi doświadczeniami i wartościami, takimi jak: zaufanie, duchowość, pobożność, bezkompromisowość, prawda;

- „służebnej” wobec wiernych, którzy oczekują od duchownego cech daleko wykraczających poza typowo ludzkie, a zmierzających niemal w stronę bóstwa. Można przypuszczać, że dla niektórych naszych respondentów ksiądz jest wręcz alter Christus, a nawet Ipse Christus (Thurian 1996).

Zebrany materiał dowiódł - co na początku nas zaskoczyło - dość słabej ekspozycji funkcji podstawowej. Wynika to najpewniej stąd, że z punktu widzenia semantyki rzeczownika ksiądz ta funkcja jest oczywista. Ponadto studenci nie tyle charakteryzowali księdza realnego, ile raczej kreowali jego własny obraz, własne wyobrażenia i marzenia o księdzu takim, jakiego chcieliby mieć (jakim powinien być), a zatem posługa względem Kościoła schodziła na plan dalszy.

Obraz księdza odtwarzany na podstawie wypowiedzi studentów lubelskich potwierdził, że w jednym stereotypie mogą spotkać się cechy zarówno pozytywne, jak i negatywne. Oceny emocjonalne, aczkolwiek wtórne wobec waloru poznawczego, stają się jednak bardzo istotne, ponieważ ujawniają uwarunkowania kulturowo-subiektywne. Ksiądz jest zatem dla respondentów i religijny, pobożny, i chciwy, wyrachowany.

Wyniki naszych badań świadczą o tym, że można mówić o coraz bardziej rysującej się - co już wcześniej sygnalizowałyśmy - ambiwalencji postaw i o znaczących przewartościowaniach w pojmowaniu księdza, jego osoby i współczesnej roli. Daje się zauważyć coraz większe słabnięcie, czy też ,zanikanie”, nienaruszalności i trwałości stereotypu osób duchownych jako ,pośredników między Bogiem a człowiekiem”, co zwykle konotowało przekonania o ich nieskazitelności, odpowiedzialności i wielu innych pozytywnych przymiotach. Obecnie, pod wpływem - nagłaśnianych coraz częściej w mediach - przypadków nagannego i gorszącego postępowania niektórych księży (afery pedofilskie, ,porzucanie kapłaństwa”, brak transparentności w rozliczaniu księży za

z Asyżu, ksiądz Anastazy z Przedwiośnia Stefana Żeromskiego, czy księża Leopold Chomski i Józef Sadzik, przywoływani w utworach Czesława Miłosza (Ksiądz Ch., po latach, Do Józefa Sadzika) itd. Zob. Kurczewski (1998, 7-13).

${ }^{10}$ Sygnalizowany problem stale znajdował i nadal znajduje odzwierciedlenie m.in. w literaturze pięknej. Wystarczy przywołać chociażby: Rozmowę mistrza Polikarpa ze śmiercia, Mikołaja Reja Rozmowę między panem, wójtem a plebanem, Ignacego Krasickiego Monachomachię, powieść Witolda Gombrowicza Kosmos, powieściową tetralogię Jana Grzegorczyka (Adieu, Trufle, Cudze pola, Jezus z Judenfeldu), wiersz Zbigniewa Herberta Homilia, powieść Matthew Gregory'ego Lewisa Mnich, trylogię Philipa Pullmanna Mroczne materie itd. Zob. Bobrowski (2010, 249-261). 
popełnione przestępstwa, jak również inne ciężkie wykroczenia) ta grupa społeczna bywa nierzadko kontestowana, postponowana, a nawet dyskryminowana (Krzyżak 2016; Janicki 2018; Szauer 2020). Na fali jednostkowych przypadków łamania prawa przez księży (które jednak sprzyjają generalizowaniu), innych - szokujących opinię publiczną - faktów, plotek i pomówień, jakie są nieodłącznym elementem komunikacji społecznej i medialnej (w tym - tabloidowej), dochodzi obecnie do znaczących przeobrażeń i przewartościowań stereotypu księdza. Obejmują one zarówno jego warstwę poznawczą, ideacyjną i wyobrażeniową, jak i sferę sądów przekonaniowych i wartościujących - czego potwierdzeniami okazały się wypowiedzi naszych respondentów. Dowodzą one również funkcjonalności stereotypu kulturowo-językowego, wykazują jego interakcyjność, dyskursywność, ale też zachowywanie cech prototypowych, które jako punkt odniesienia stają się ważnymi elementami konstrukcji każdego stereotypu (por. Tambor 2008, 23-29).

Stereotyp księdza rekonstruowany przez nas świadczy o tym, że realia współczesności (językowe, komunikacyjno-kulturowe, aksjologiczne, obyczajowe, medialne) sprzyjają przekształcaniu, odnowie, zmianie tego, co w kulturze zastane, przy czym ankiety, które analizowałyśmy, dowodzą, że można obecnie mówić o przełomie i ewolucji poglądów, ocen, postaw i oczekiwań wobec księży ${ }^{11}$. Można z wyników odczytać świadectwo konstruktywnego zrywania nie tyle ze stereotypem rozumianym jako sprawdzone i użyteczne narzędzie interpretacji, argumentacji, komunikacji, dyskursu, ile ze stereotypem pojmowanym jako struktura czy schemat/model myślenia, przeżywania, komunikowania i działania ograniczający człowieka, narażający go na uproszczenie percypowanej rzeczywistości, a przez to niosący ryzyko jej zafałszowywania, powierzchownego oglądu, niezrozumienia.

Analiza materiału ankietowego, do którego odwołujemy się w tym artykule oraz badania i przemyślenia innych autorów wypowiadających się na temat współczesnych księży (Draguła 2020a, 2020b) przekonują jednak, że mimo wyraźnych zmian, jakim ulega obecnie stereotyp księdza, istotne w tym obrazie pozostają wymiar rytualny i wspólnotowy, jak również otwartość na dialog i na religijne potrzeby ludzi wierzących ${ }^{12}$.

\footnotetext{
${ }^{11}$ Nasze konstatacje są zbliżone do wypowiedzi Remigiusza Szauera w artykule „Ksiądz, który jest w porządku”: ,[...] «nie ma „zapotrzebowania» na kapłaństwo, czy raczej na pewien styl realizowania posługi kapłańskiej (który odbierany jest społecznie jako swoista norma): krzyczący, wykluczający, imperatywny, monotonny, upolityczniony, moralizatorski, pogardliwie pobłażliwy, arogancki, materialistyczny czy sprawiający wrażenie oderwania od życia [...] wyraźnie widać, że autorytet instytucjonalny nie odgrywa już istotnego znaczenia, natomiast liczyć się może jedynie autorytet indywidualnie i wiarygodnie budowany" (Szauer 2019b).

${ }^{12}$ Interesująco pisze na ten temat Andrzej Draguła (2020a). Gdy odwołuje się do aktualnych badań nad problemami współczesnego Kościoła, eksponuje walory modelu posługi kapłańskiej, który określa jako „ofiarniczo-wstawienniczy”. Jednym z jego wyznaczników jest łączenie - w pracy duszpasterskiej - wstawiennictwa i służby oraz pośrednictwa i jednoczenia ludzi.
} 


\section{BIBLIOGRAFIA}

Bartmiński, J. 1998. „Podstawy lingwistycznych badań nad stereotypem - na przykładzie stereotypu matki”. W Stereotyp jako przedmiot lingwistyki, red. J. Anusiewicz, i J. Bartmiński. Wrocław: Towarzystwo Przyjaciół Polonistyki Wrocławskiej, 63-68 (Język a Kultura, t. 12).

Bartmiński, J., red. 2006. Język - wartości - polityka. Zmiany rozumienia nazw wartości w okresie transformacji ustrojowej w Polsce. Raport z badań empirycznych. Lublin: Wydawnictwo Uniwersytetu Marii Curie-Skłodowskiej.

Bartmiński, J. 2007. Stereotypy mieszkają w języku. Studia etnolingwistyczne. Lublin: Wydawnictwo Uniwersytetu Marii Curie-Skłodowskiej.

Bartmiński, J. 2011. „O stereotypach i profilowaniu słów kilka”. W Stereotypy - walka z wiatrakami?, red. A. Bujanowska, i J. Szadura. Lublin: Wydawnictwo Uniwersytetu Marii Curie-Skłodowskiej, 33-51.

Bartmiński, J., i J. Panasiuk. 1993. „Stereotypy językowe”. W Encyklopedia kultury polskiej XX wieku. Wspótczesny język polski, t. 2, red. J. Bartmiński. Wrocław: Wydawnictwo „Wiedza o Kulturze” - Instytut Filologii Polskiej UMCS, 363-387.

Berting J., i Ch. Villain-Gandossi. 1995. „Rola i znaczenie stereotypów narodowych w stosunkach międzynarodowych: podejście interdyscyplinarne". tłum. J. Piątkowska. W Narody i stereotypy, red. T. Walas. Kraków: Międzynarodowe Centrum Kultury, 13-27.

Biernat, M. 1991. „Gender Stereotypes and The Relationship Between Masculinity and Feminity: A Developmental Analysis". Journal of Personality and Social Psychology 61: 351-365.

Bobrowski, A. 2010. „Kapłan i kapłaństwo w kręgu tematów literackich”. Ruch Biblijny i Liturgiczny 5: 249-261.

Chlebda, W. 1998. „Stereotyp jako jedność języka, myślenia i działania”. W Stereotyp jako przedmiot lingwistyki, red. J. Anusiewicz, i J. Bartmiński. Wrocław: Towarzystwo Przyjaciół Polonistyki Wrocławskiej, 31-41 (Język a Kultura, t. 12).

Chodkowska, M. 2009. „Antyczne korzenie współczesnych stereotypów”. W Stereotypy - walka z wiatrakami?, red. A. Bujanowska, i J. Szadura. Lublin: Wydawnictwo Uniwersytetu Marii Curie-Skłodowskiej, 13-32.

Draguła, A. 2020a. „Dwa kościoły”. Tygodnik Powszechny 28.

Draguła, A. 2020b. „Kapłańska futurologia”. Tygodnik Powszechny 25.

Fleischer, M. 2002. „Stereotypy”. W Teoria kultury i komunikacji. Systemowe i ewolucyjne podstawy. Wrocław: Dolnośląska Szkoła Wyższa Edukacji Towarzystwa Wiedzy Powszechnej, 445-449.

Gnitecki, J. 1998. Zasada ambiwalencji zrównoważonej i zasada spójności w filozofii, nauce i edukacji. Poznań: Wydawnictwo Naukowe Towarzystwa Pedagogicznego.

Habrajska, G. 2008. „Stereotyp w komunikacji”. Postscriptum Polonistyczne 1: 13-21.

Janicki, Ł., red. 2018. RYSopis kaptana. Wizerunek księdza w kulturze polskiej w XXI wieku. Lublin: Gaudium.

Karwatowska, M., i I. Morawska. 2021. „Ksiądz w opiniach studentów lubelskich”. Prace Językoznawcze 23 (1): 123-136.

Kochan, M. 1994. „Przyklejanie etykietek, czyli o negatywnym określaniu przeciwnika”. W Język polityki a współczesna kultura polityczna, red. J. Anusiewicz, i B. Siciński. Wrocław: Towarzystwo Przyjaciół Polonistyki Wrocławskiej, 85-89 (Język a Kultura, t. 11).

Kominek, A. 2003. Punkt zborny. Obraz Kościoła katolickiego w Polsce w tekstach publicystycznych z lat 1970-1989. Kielce: Wydawnictwo Uniwersytetu Jana Kochanowskiego. 
Krzyżak, T. 2016. „Dyskryminacja księży to nie rzadkość”. Rzeczpospolita 22.

Kurczewski, J. 1998. „Kapłan, król, wódz - stare postaci w nowej rzeczywistości”. W Obraz wodza, kapłana, króla w kulturach stowiańskich, red. T. Dą̧bek-Wirgowa, i A.Z. Makowiecki. Warszawa: Uniwersytet Warszawski. Wydział Polonistyki, 7-13.

Lippmann, W. 1922. Public Opinion. New York.

Łukaszewski, W., i B. Weilg. 2001. „Stereotyp stereotypu czy prywatna koncepcja natury ludzkiej?”. W Stereotypy i uprzedzenia. Uwarunkowania psychologiczne i kulturowe, red. M. Kofta, i A. Jasińska-Kania. Warszawa: Wydawnictwo Naukowe Scholar.

Mackie, D.M. i in. 1999. „Społeczno-psychologiczne podstawy powstawania stereotypów”. W: Stereotypy i uprzedzenia. Najnowsze ujęcie, red. C.N. Macrae, Ch. Stangor, i M. Hewstone. tłum. M. Majchrzak. Gdańsk: Gdańskie Wydawnictwo Psychologiczne, 39-65.

Macrae C.N., Ch. Stangor, i M. Hewstone, red. 1999. Stereotypy i uprzedzenia. Najnowsze ujęcie. thum. M. Majchrzak. Gdańsk: Gdańskie Wydawnictwo Psychologiczne.

Miszewski, B. 1998. „Stereotypy we współczesnym polskim dyskursie kaznodziejskim”. W Stereotyp jako przedmiot badań lingwistyki. Teoria, metodologia, analizy empiryczne, red. J. Anusiewicz, i J. Bartmiński. Wrocław: Towarzystwo Przyjaciół Polonistyki Wrocławskiej, 224-238 (Język a Kultura, t. 12).

Nowak-Łojewska, A. 2002. Zrównoważenie i uspójnienie struktur poznawczych i obrazowania językowego w procesie ksztatcenia. Kraków: Impuls.

Nowak-Łojewska, A. 2005. „Zasada ambiwalencji zrównoważonej w służbie rozwoju człowieka na miarę XXI wieku". W Fundamenty edukacyjnej wspólnoty, red. J. Danielewska. Kraków: Wydawnictwo Uniwersytetu Jagiellońskiego, 247-255.

Panasiuk, J. 1998. O zmienności stereotypów. W Stereotyp jako przedmiot lingwistyki, red. J. Anusiewicz, i J. Bartmiński. Wrocław: Towarzystwo Przyjaciół Polonistyki Wrocławskiej, 84-98 (Język a Kultura, t. 12).

Piaget, J. 2005. Mowa i myślenie dziecka. tłum. J. Kołudzka. Warszawa: Wydawnictwo Naukowe PWN.

Pilch, T. 1998. Zasady badań pedagogicznych. Warszawa: Wydawnictwo Żak.

Przeciszewski, M., red. 2012. Kościót: stereotypy, uprzedzenia, manipulacje. Lublin: Wydawnictwo Archidiecezji Lubelskiej Gaudium.

Quasthoff, U.M. 1998. Etnocentryczne przetwarzanie informacji. Ambiwalencja funkcji stereotypów w komunikacji międzykulturowej. W Stereotyp jako przedmiot lingwistyki, red. J. Anusiewicz, i J. Bartmiński. Wrocław: Towarzystwo Przyjaciół Polonistyki Wrocławskiej, 11-30 (Język a Kultura, t. 12).

Sawicka, G. 1993. „Rola stereotypu w nominacji językowej”. W Mity i stereotypy w kulturze, literaturze i języku, red. M. Kozłowska, i E. Tierling. Szczecin: Wydawnictwo Naukowe Uniwersytetu Szczecińskiego, 7-16.

Sikora, P. 2020. „Kościół bez duchowieństwa”. Tygodnik Powszechny 27: 41-43.

Szauer, R. 2019a. Między potrzeba doznań a trwatościa postaw. Religijność i moralność uczniów szkót średnich i studentów uczelni wyższych $w$ diecezji koszalińsko-kołobrzeskiej. Studium socjologiczne. Warszawa: Warszawskie Wydawnictwo Socjologiczne.

Szauer, R. 2019b. „Ksiądz, który jest w porządku”. https://wiez.pl/2019/11/29/ksiadz-ktory-jest-w-porzadku/ (25 kwietnia 2020).

Szauer, R. 2020. „Między dystansem a potrzebą. Stosunek młodzieży akademickiej do Kościoła i duchowieństwa. Studium socjologiczne". Przegląd Religioznawczy 2: 129-145.

Tambor, J. 2008. „Stereotyp i prototyp - znaczenia terminów”. Postscriptum Polonistyczne 1: 23-29. 
Thurian, M. 1996. Tożsamość kapłana. tłum. J. Machniak. Kraków: Znak.

Treder, J. 2007. „Leksemy «papież» i «biskup» we frazeologii (nie tylko polskiej)”. W Język-szkoła - religia, t. 2, red. A. Lewińska, i M. Chmiel. Pelplin: Wydawnictwo „Bernardinum”, 375-381.

Treder, J. 2008. „Leksem «ksiądz» i bliskoznaczne we frazeologii (nie tylko polskiej)”. W: Język-szkołareligia, t. 3, red. A. Lewińska, i M. Chmiel. Pelplin: Wydawnictwo „Bernardinum”, 333-344.

Warda-Radys, L., i A. Lewińska. 2011. „Obraz księdza w podręcznikach do religii (gimnazjum i liceum)”. Język - Szkoła-Religia 6: 462-496.

Wasiuta, S. 2009. „Stereotyp - pojęcie kluczowe lubelskiej etnolingwistyki”. W Stereotypy w języku i kulturze, red. S. Niebrzegowska-Bartmińska, i S. Wasiuta. Lublin: Polihymnia, 11-23.

Witkowski, L. 1994. „Ambiwalencja i sacrum”. W Nieobecne dyskursy, t. 4, red. Z. Kwieciński. Toruń: Wydawnictwo Naukowe Uniwersytetu Mikołaja Kopernika.

Zanussi, K. 1995. „Stereotypy narodowe w filmie”. W: Narody i stereotypy, red. T. Walas. Kraków: Międzynarodowe Centrum Kultury, 209-218.

\title{
On a Stereotype of the "Typical" and "True" Priest: a Questionnaire Survey
}

Keywords: stereotype, a "typical" priest, a "true" priest, student, questionnaire, survey.

\begin{abstract}
The article presents the findings that have emerged from a student-addressed questionnaire survey on a stereotype of, respectively, "typical" priest and "true" priest. The diagnostic study was carried out at the Faculty of Humanities at Maria Curie-Skłodowska University in Lublin. The theoretical grounding for the analysis stems from the two research methodologies, that is, a psychosociocultural and ethnocognitive ones. As evidenced in the article, the "typical" representative can be ascribed with the attributes of a priest that the students either know in person or they know from some independent communication, mass-media coverage included. This is the reason why the image of the priest happens to be ambivalent, that is, it includes both positive as well as negative shades of attitude. In reference to the "true" priest, in turn, the students tend to point to positive characteristics only, depicting the priest as they wish he were, which explains why elements of strong idealisation and wishful thinking can be identified in the students' responses. It has been found that students perceive the priest with respect to two functions: (1) basic - natural, connected with serving the Church, and therefore associated with positive experiences and values such as trust, spirituality, piety, intransigence and truth, (2) "serving" the believers who expect a clergyman to possess characteristics going far beyond typically human, and being almost god-like. The collected data has demonstrated a rather weak exposition of the former function, which can be explained by the fact that this function is obvious from the point of view of the semantics of the priest. Moreover, the respondents did not in fact provide the characteristics of a real priest but rather created an image of him, their own perception of a priest they would like to have (i.e. what the priest should be like), which made serving the Church an issue of lesser importance. The image of the priest which has been recreated on the basis of students' statements has confirmed that both positive and negative characteristics can be combined in a single stereotype. Emotional assessments, albeit secondary to the cognitive valour, are still quite significant, as they reveal the cultural-subjective conditioning. The priest is therefore both religious and pious, and greedy and calculating for the respondents.
\end{abstract}

